Studia nad Autorytaryzmem i Totalitaryzmem 43, nr 3 Wrocław 2021

https://doi.org/10.19195/2300-7249.43.3.34

ANDRZEJ WRZYSZCZ

ORCID: 0000-0002-9824-4251

Uniwersytet Marii Curie-Skłodowskiej w Lublinie andrzej.wrzyszcz@poczta.umcs.lublin.pl

\title{
Sądownictwo polskie w Generalnym Gubernatorstwie. Refleksje o najnowszej książce Andrzeja Szulczyńskiego
}

Słowa kluczowe: sądownictwo polskie, Generalne Gubernatorstwo, okupacja niemiecka, druga wojna światowa.

\section{POLISH JUDICIARY IN THE GENERAL GOVERNMENT: REFLECTIONS ON THE LATEST BOOK BY ANDRZEJ SZULCZYŃSKI}

\begin{abstract}
The monograph discussed in this review article is not a comprehensive synthesis which fully covers the complex issues of the organization and functioning of the Polish judiciary in the General Government during the Second World War. The opinions formulated in the paper are polemical and often critical. However, many of the facts presented by Andrzej Szulczyński are completely new and significantly expand the state of our knowledge. The findings made by the author and the conclusions he formulated in the monograph will constitute an impulse for further research on the judiciary in Poland under German occupation during the Second World War, which I believe is necessary.

Keywords: Polish judiciary, General Government, German occupation, Second World War.

Na początku 2018 roku od naczelnika Wydziału Wydawniczego Wydawnictwa Instytutu Pamięci Narodowej Komisji Ścigania Zbrodni przeciwko Narodowi Polskiemu otrzymałem do recenzji wydawniczej tekst (w postaci wydruku komputerowego) pt. Sadownictwo polskie w Generalnym Gubernatorstwie 19391945. Autorem tego opracowania liczącego 143 strony był Andrzej Szulczyński.
\end{abstract}


W drugiej połowie kwietnia 2018 roku przygotowałem recenzję wydawniczą, w której przeważały oceny krytyczne.

W 2020 roku opublikowana została monografia Andrzeja Szulczyńskiego pod tym samym tytułem w Wydawnictwie Słowo ${ }^{1}$. Zamieszczone w niej dane bibliograficzne nie zawierają informacji o recenzencie wydawniczym. W tej sytuacji uznałem za właściwe przedstawienie moich uwag na temat tej publikacji w niniejszym artykule recenzyjnym.

$\mathrm{Na}$ wstępie chciałbym stwierdzić, że książka ogłoszona drukiem w 2020 roku wyraźnie różni się od recenzowanego przeze mnie tekstu w postaci wydruku komputerowego z 2018 roku. Jest ona znacznie obszerniejsza, zwiększono ją o kilkadziesiąt stron. W istotnym stopniu zmieniona została struktura wewnętrzna tego opracowania. Autor uwzględnił pewną część moich uwag i sugestii odnoszących się do kwestii merytorycznych i metodologicznych.

Pragnę podkreślić, że wysoko oceniam wybór problematyki badawczej. Organizacja i funkcjonowanie oficjalnego sądownictwa polskiego w Generalnym Gubernatorstwie w latach 1939-1945, znajdującego się pod nadzorem niemieckim, to „biała plama” w polskiej historiografii. Przez kilkadziesiąt lat po zakończeniu drugiej wojny światowej był to temat tabu. Dopiero od lat osiemdziesiątych XX wieku zaczęły pojawiać się publikacje, które opierały się niemal wyłącznie na analizie aktów normatywnych ustanowionych przez niemieckie władze okupacyjne dla Generalnego Gubernatorstwa. Autorzy bardzo rzadko sięgali do danych ilustrujących praktykę działania tego sądownictwa ${ }^{2}$. Od kilkunastu lat ukazują się drukiem pozycje odwołujące się do źródeł archiwalnych w postaci zachowanych akt sądowych. Są to opracowania o dużym stopniu szczegółowości (konkretne instytucje procesowe, ograniczenia wprowadzone przez autorów ze względu na narodowość podsądnych czy właściwość miejscową sądów). Kilka prac odnosi się do statusu ludności żydowskiej przed sądami polskimi ${ }^{3}$. Brakowało dotąd

1 A. Szulczyński, Sądownictwo polskie w Generalnym Gubernatorstwie 1939-1945, Warszawa $2020,194 \mathrm{~s}$.

2 Na przykład J. Mazurkiewicz, L. Policha, Dzieje sądownictwa lubelskiego w latach 19151944, razem z notatką J. Mazurkiewicza i L. Polichy o stratach w lubelskim sądownictwie, stworzoną na podstawie protokołów Miejskiej Komisji Badania Zbrodni Niemieckich w Lublinie, praca nieopublikowana, mpis przechowywany w Katedrze Historii Państwa i Prawa UMCS w Lublinie; M. Sworzeń, Sadownictwo polskie w Generalnym Gubernatorstwie, „Prawo i Życie” 1987, nr 40; idem, Sędziowie w podbitym kraju. Oficjalne sadownictwo polskie w Generalnym Gubernatorstwie 1939-1945, „Zeszyty Historyczne” 1999, z. 128; J. Szarycz, Sędziowie i sądy w Polsce w latach 1918-1988, Warszawa 1988; A. Wrzyszcz, O organizacji okupacyjnego sadownictwa polskiego w Generalnym Gubernatorstwie w latach 1939-1945, „Zeszyty Majdanka” 14, 1992.

3 J. Grabowski, Żydzi przed obliczem niemieckich i polskich sądów $w$ dystrykcie warszawskim Generalnego Gubernatorstwa, 1939-1942, [w:] Prowincja noc. Życie i zaglada w dystrykcie warszawskim, red. B. Engelking, J. Leociak, D. Libionka, Warszawa 2007; idem, Zarzad powierniczy i nieruchomości żydowskie w Generalnym Gubernatorstwie, [w:] Klucze i kasa. O mieniu żydowskim w Polsce pod okupacja niemiecka $i$ we wczesnych latach powojennych 1939-1950, red. J. Grabowski, D. Libionka, Warszawa 2014; B. Engelking, J. Grabowski, „Przestępczość” Żydów 
syntezy całościowo ujmującej tę skomplikowaną problematykę. Recenzowana monografia Andrzeja Szulczyńskiego to próba wypełnienia tej luki.

Interesujące jest stanowisko autora w kwestii znaczenia oficjalnego sądownictwa okupacyjnego dla mieszkańców Generalnego Gubernatorstwa:

że skoro polski sąd grodzki w Warszawie w jednym miesiącu (kwietniu 1943 r.) rozpatrywał jednak aż 2244 sprawy karne i 1449 spraw cywilnych, to jego funkcjonowanie nie było bynajmniej marginesem, lecz całkiem poważnym i ważnym fragmentem codziennego życia wielu mieszkańców GG, tutaj warszawian. Wszak w tym jednym tylko miesiącu przez korytarze sądowe i sale rozpraw warszawskiego sądu przewinąc się musiały tysiące ludzi — oskarżonych, pozwanych, powodów, świadków, poszkodowanych, adwokatów, prokuratorów. Dla przygniatającej ich większości udział $\mathrm{w}$ rozprawach i werdykt sądu były ważnymi wydarzeniami w istotnych sprawach życiowych. (s. 12)

Podzielam ten pogląd, chociaż w wypadku mniejszych ośrodków aktywność lokalnych sądów była znacznie mniejsza.

Struktura książki obejmuje cztery rozdziały (wyodrębnione na podstawie kryterium merytorycznego), a poza tym wstęp, zakończenie, wykaz źródeł i literatury, podsumowanie w języku niemieckim oraz indeks nazwisk. Konstrukcję tę można zaaprobować, chociaż wewnętrzny podział niektórych rozdziałów na punkty bądź podpunkty oceniam z dużą dozą krytycyzmu (wrócę do tej kwestii dalej).

Wstęp zawiera typowe dla monografii elementy: cel pracy, konstrukcja, podstawa źródłowa, uwagi terminologiczne. Autor zamieścił tu jednak także inne kwestie. Niektóre z nich zasługują na aprobatę, inne zostały moim zdaniem nadmiernie rozbudowane. W rezultacie objętość wstępu (22 strony) jest niewspó1miernie duża w porównaniu z rozmiarami całej pracy (194 strony). Wątpliwa wydaje mi się potrzeba omawiania polityki zagranicznej Niemiec w latach 19341939. Wprawdzie w porównaniu z wersją z 2018 roku fragment ten został zgodnie z moimi sugestiami znacznie ,odchudzony”, ale nadal nie dostrzegam jego bezpośredniego związku z tematem recenzowanej monografii. Kluczowa wydaje się tu rozbieżność między naszymi poglądami w kwestii wpływu długofalowej polityki III Rzeszy na organizację oficjalnego sądownictwa polskiego w Generalnym Gubernatorstwie funkcjonującego pod nadzorem niemieckich władz okupacyjnych. Na s. 20 Andrzej Szulczyński stwierdza: „Podjęta została próba odpowiedzi na pytanie, jakie cele strategiczne przyświecały Niemcom w tym aspekcie polityki okupacyjnej. Na ile polskie sądownictwo miało »odciążać«

w Warszawie 1939-1942, Warszawa 2010; H. Mielnik, Sadownictwo polskie (nieniemieckie) $w$ dystrykcie lubelskim Generalnego Gubernatorstwa w latach 1939-1945, Lublin 2020; idem, Prawo sprawdzenia prawomocnych orzeczeń sądów polskich (nieniemieckich) w Generalnym Gubernatorstwie w okresie II wojny światowej. Orzecznictwo Wyższego Sądu Niemieckiego w Radomiu, „Czasopismo Prawno-Historyczne” 72, 2020, z. 1; idem, The legal status of the Jews in proceedings before the Polish (non-German courts in the Lublin district of the General Governement during World War II, „Acta historico-iuridica Pilsnensia” 2018; E. Wiatr, Na marginesie funkcjonowania sadów polskich w Generalnym Gubernatorstwie. Przypadek Majera Wolberga, „Zagłada Żydów. Studia i materiały. Pismo Centrum Badań nad Zagładą Żydów IFiS PAN” 2015, nr 11. 
niemiecki aparat, na ile zaś służyło wprzęgnięciu Polaków w system sprawowania władzy". Według mnie kwestia okupacyjnego sądownictwa w GG zupełnie nie była uwzględniana przy tworzeniu strategicznych celów Niemiec, a decyzje w tej sprawie podejmowane były ad hoc i wynikały z bieżącej sytuacji militarnej, politycznej, gospodarczej.

Za nieprecyzyjne uważam stwierdzenie Andrzeja Szulczyńskiego: „Od końca 1940 roku w Generalnym Gubernatorstwie działało 159 polskich sądów grodzkich w charakterze sądów pierwszej instancji, a ponadto wznowiły orzekanie odpowiednio polskie sądy okręgowe i apelacyjne" (s. 12). W rzeczywistości Sąd Apelacyjny w Radomiu nie wznowił orzekania, bo przed wybuchem drugiej wojny światowej nie istniał. Niemcy utworzyli go podczas okupacji, aby dostosować podział terytorialny dla administracji ogólnej z podziałem terytorialnym dla celów sądowych. Autor pisze o tym dalej (s. 67), więc tym bardziej dziwi, że we wstępie zamieścił nieścisłą informację.

Punkt 3 wstępu pt. Uwagi bibliograficzne zostanie przeze mnie omówiony wraz z całą bibliografią. Punkt $4 \mathrm{pt}$. Uwagi terminologiczne jest niewątpliwie bardzo potrzebny. Autor zajął się tu czterema pojęciami, które nie są jednolicie używane w dotychczasowej literaturze naukowej. Pierwsza kwestia to niekonsekwentne nazewnictwo: Generalne Gubernatorstwo czy Generalna Gubernia? Wyjaśnienia A. Szulczyńskiego w tym zakresie są klarowne i precyzyjne, zasługują na pełną aprobatę. Nie mam też zastrzeżeń do rozważań na temat używania nazw: okręg czy dystrykt. Akceptuję wywody autora odnoszące się do tych kwestii terminologicznych.

Wątpliwości budzi natomiast uzasadnienie konieczności stosowania pojęcia „wymiar sprawiedliwości”. Andrzej Szulczyński pisze:

Niemiecki termin Justiz nie ma w pełni adekwatnego odpowiednika polskiego, ponieważ zawiera w sobie zarówno polskie pojęcie ,wymiaru sprawiedliwości” sensu stricto, jak i administrację organów wymiaru sprawiedliwości. Justizbehörde jest thumaczone zamiennie jako „władza sądowa”, lub „organ wymiaru sprawiedliwości.

W pracy opisującej sądy w Generalnym Gubernatorstwie nie sposób było uniknąć terminu „wymiar sprawiedliwości” czy „organy wymiaru sprawiedliwości”, aczkolwiek określenie zawierające pojęcie „sprawiedliwość” w oczywisty sposób stoi w sprzeczności z systemem stworzonym przez okupanta, systemem represyjnym i opresyjnym, realizującym zbrodnicze cele polityczne III Rzeszy. Zatem termin ,wymiar sprawiedliwości” używany jest tu tylko w sensie formalnym i opisowym.

Wyjaśnienie to zamieszczone we wstępie jasno pokazuje intencje autora i usprawiedliwia stosowaną $\mathrm{w}$ monografii terminologię. Wydaje mi się jednak, że nazwa „organy wymiaru sprawiedliwości” nie była bezwzględnie konieczna, proponuję stosowane przeze mnie bardziej neutralne określenie „organy resortu 
sprawiedliwości" ${ }^{4}$. Zwracam także uwagę na niekonsekwentne używanie nazewnictwa tych samych podmiotów. W monografii używane są na przykład nazwy: Główny Wydział Wymiaru Sprawiedliwości, dystryktowe wydziały wymiaru sprawiedliwości, ale można znaleźć też określenia: Główny Wydział Sprawiedliwości, działy sprawiedliwości w dystryktach (na przykład s. 17, 38, 42, 44, 45 i in.).

Kolejna kontrowersja terminologiczna dotyczy rozróżnienia pojęć: „sądownictwo polskie" i ,sądownictwo nieniemieckie”. Nie ulega wątpliwości, że nazwa „sądownictwo polskie” w Generalnym Gubernatorstwie jest w pełni właściwa do okresu od 26 października 1939 roku $^{5}$ do 31 sierpnia 1941 roku. Od przyłączenia do GG nowego piątego dystryktu Galicja 1 sierpnia 1941 roku wprowadzono nowe pojęcie: "sądownictwo nieniemieckie" ". Odtąd w aktach normatywnych wydawanych przez niemieckie władze okupacyjne i publikowanych w Dzienniku Rozporządzeń dla Generalnego Gubernatorstwa nazwa „sądownictwo polskie” już się nie pojawia. Używane było natomiast miano „sądownictwo nieniemieckie” w stosunku do oficjalnego sądownictwa okupacyjnego dla ludności nieniemieckiej we wszystkich pięciu dystryktach. Według A. Szulczyńskiego w aktach wewnętrznych organów resortu sprawiedliwości GG (pisma kierownika Głównego Wydziału Sprawiedliwości) można znaleźć nazwę „sądownictwo polskie” także po sierpniu 1941 roku. Decyzja autora recenzowanej monografii o kryterium rozróżnienia pojęcia „sądownictwo polskie” i „sądownictwo nieniemieckie” po 1 sierpnia 1941 roku budzi jednak moje wątpliwości. Szulczyński na s. 25 stwierdza:

W niniejszej pracy stosowane są określenia „sądownictwo polskie” i ,sądy polskie” w odniesieniu do sądów polskich istniejących w GG w dystryktach krakowskim, lubelskim, radomskim i warszawskim, zaś ,sądownictwo nieniemieckie” i ,sądy nieniemieckie” w stosunku do sądów w okręgu Galicja.

Według mnie takie założenie może wprowadzać czytelników w błąd. Może rozwiązaniem byłoby dodanie w tytule książki w nawiasie nazwy „sądownictwo nieniemieckie" po słowach sądownictwo polskie?

Rozdział pierwszy ma charakter wprowadzający. Autor przedstawił w nim podstawy ustroju Generalnego Gubernatorstwa oraz strukturę organizacyjną resortu sprawiedliwości GG. Wyodrębnił trzy punkty: 1. Status ustrojowoprawny $G G, 2$. Administracja wymiaru sprawiedliwości w $G G, 3$. Dualistyczny system sadownictwa powszechnego GG. Rozdział ten stanowi solidne wprowadzenie

${ }^{4}$ Używanie tej neutralnej terminologii zasugerował mi wiele lat temu wybitny historyk ustroju i prawa prof. Adam Lityński.

5 A. Weh, Prawo Generalnego Gubernatorstwa w układzie rzeczowym z objaśnieniami i szczególowym skorowidzem, (wydanie trzecie podpisane przez A. Weha 31 grudnia 1940 r.), Kraków 1941, C 100, rozporządzenie o odbudowie wymiaru sprawiedliwości w Generalnym Gubernatorstwie z dnia 26 października 1939 r. $§ 1$.

${ }^{6}$ Rozporządzenie w sprawie odbudowy wymiaru sprawiedliwości w okręgu Galizien (Galicja) z dnia 1 sierpnia 1941 r., Dziennik Rozporządzeń dla Generalnego Gubernatorstwa 1941, nr 68, s. $445-446, \S 1,2$. 
do dalszych rozważań. Oparty został na dotychczasowej literaturze naukowej i znanych źródłach drukowanych, ale warto podkreślić, że Szulczyński wykorzystał też swoje badania archiwalne. Dzięki nim poszerzył dotychczasowy stan naszej wiedzy, zwłaszcza odnośnie do aktywności organów administracji resortu sprawiedliwości. Na dojrzałym poziomie stoją wywody charakteryzujące funkcjonowanie dualistycznego systemu sądownictwa powszechnego w Generalnym Gubernatorstwie.

Do obowiązków recenzenta należy jednak także wskazanie na pewne wątpliwości. Istotną kwestią poruszaną w punkcie 3 rozdziału pierwszego jest instytucja prawa sprawdzenia prawomocnych wyroków sądów polskich. Początek jej omawiania to s. 54, a kontynuacja następuje po przerwie na s. 55-56. Autor powołuje się tu między innymi na analizę akt sądowych Wyższego Sądu Niemieckiego w Radomiu. Są one przechowywane w Archiwum Państwowym w Radomiu w zespole Niemiecki Sąd Wyższy w Radomiu (w monografii podano nieco inną nazwę: Sąd Wyższy Prawa Niemieckiego). Wyniki tej analizy są jednak odmienne od ustaleń poczynionych $\mathrm{w}$ opublikowanym $\mathrm{w}$ ostatnich miesiącach artykule Huberta Mielnika ${ }^{7}$. Rozbieżności te należy moim zdaniem szczegółowo wyjaśnić.

Na s. 29 autor słusznie stwierdza, że Frank, wydając rozporządzenia, powoływał się na $\S 5$ dekretu Führera z dnia 12 października 1939 roku $^{8}$. Błędnie jednak przypisuje kierownikowi Wydziału Sprawiedliwości (Głównego Wydziału Sprawiedliwości) Kurtowi Willemu publikowanie rozporządzeń wykonawczych z podkreśleniem, że opierają się one ,także na woli Führera”. Po pierwsze, Wille nie opublikował w dzienniku rozporządzeń żadnego rozporządzenia wykonawczego, a po drugie, rozporządzenia wykonawcze wydawane przez inne podmioty w GG nie odwoływały się bezpośrednio do „woli Führera”. Nie zgadzam się ze zdaniem: „wszystkie postępowania przed sądami polskimi w GG toczyły się wyłącznie w języku polskim, wszystkie pisma były wnoszone po polsku [...]" (s. 56). Według mnie istniały wyjątki na rzecz języka ukraińskiego.

W rozdziale drugim Szulczyński scharakteryzował status sądownictwa polskiego. W punkcie 1 przedstawił podstawy prawne jego funkcjonowania. Większość wymienionych tu aktów normatywnych wskazana została już w rozdziale pierwszym, autor nie uniknął więc kilku powtórzeń, ale zaletą jest niewątpliwie zebranie tych przepisów w jednym miejscu i uporządkowanie. Uzupełnieniem są rozporządzenia, które nie były dotąd wykorzystywane w monografii, odnoszące się do kwestii formalnych (godło, formuła wyrokowania, łańcuchy sędziów), ferii

${ }^{7}$ H. Mielnik, Prawo sprawdzenia..., s. 239.

8 A. Weh, op. cit., A 100, dekret Führera i Kanclerza Rzeszy Niemieckiej o administracji okupowanych polskich obszarów z dnia 12 października 1939 r. § 5. Na s. 30 monografii czytamy: „Ogólna definicja statusu publicznoprawnego Generalnego Gubernatorstwa określona w § 7 wyżej cytowanego dekretu... wyglądała tak: Generalne Gubernatorstwo jest osobą prawną o własnych prawach i zobowiązaniach; generalny gubernator i upoważnione przez niego organy reprezentują je na zewnątrz”. W treści § 7 nie znajduję tych postanowień. 
sądowych, odesłania do prawa obowiązującego w Krakowie (siedziba generalnego gubernatora) zamiast Warszawy, pomocy prawnej między sądami polskimi a organami wymiaru sprawiedliwości Rzeszy Niemieckiej oraz Protektoratu Czech i Moraw.

W punkcie 2 omówiono organizację sądownictwa polskiego i sytuację polskich sądowników w Generalnym Gubernatorstwie. Na podstawie dotychczasowej literatury naukowej i opublikowanych źródeł przedstawiony został proces wznawiania funkcjonowania polskich sądów pod okupacją niemiecką w GG, a także reorganizacja jego struktury (zawieszenie działalności Sądu Najwyższego, utworzenie Sądu Apelacyjnego w Radomiu). Uwzględniono tworzenie sądownictwa nieniemieckiego w nowym piątym dystrykcie Galicja włączonym do Generalnego Gubernatorstwa 1 sierpnia 1941 roku. Na uznanie zasługują rozważania odnoszące się do statusu polskich sędziów. Andrzej Szulczyński szczegółowo omówił kwestię obowiązkowego podpisywania przez nich „deklaracji posłuszeństwa”. Słusznie sięgnął do reakcji Polskiego Państwa Podziemnego na wymagania stawiane przez Niemców, powołując się na konspiracyjny kodeks moralności obywatelskiej. Interesujące są też wywody na temat rozgraniczania właściwości rzeczowej sądów między pionem sądownictwa niemieckiego a pionem sądownictwa polskiego (nieniemieckiego) oraz informacje odnoszące się do egzaminów polskich aplikantów sędziowskich. W punkcie tym autor korzystał między innymi z zasobów aktowych Archiwum Państwowego w Kielcach, ale dziwi, że właśnie tu przedstawił dane liczbowe, chronologiczne i merytoryczne na temat jednego zespołu (zespół nr 1134 Sąd Okręgowy w Kielcach). Informacje te powinny być zamieszczone w punkcie 3 wstępu.

Punkt 3 rozdziału drugiego zawiera skrótową charakterystykę prawa obowiązującego w Rzeczypospolitej Polskiej przed wybuchem drugiej wojny światowej. Wybrano podstawowe $\mathrm{w}$ funkcjonowaniu sądownictwa gałęzie prawa: prawo o ustroju sądów powszechnych, prawo cywilne materialne i procesowe, prawo karne materialne i procesowe. Synteza każdego działu zakończona jest charakterystyką najważniejszych zmian wprowadzonych przez okupanta niemieckiego w Generalnym Gubernatorstwie. Punkt ten ma znaczenie porządkujące, ułatwia czytelnikowi percepcję orzecznictwa sądownictwa polskiego (nieniemieckiego) w realiach okupacyjnych. Moja drobna uwaga dotyczy prawa cywilnego materialnego. Autor słusznie zauważył, że w GG nie obowiązywał tom dziesiąty Zwodu Praw, nie dodał (a szkoda), iż dotyczy to też kodeksu niemieckiego (BGB z 1896 roku).

Punkt 4 nosi tytuł: Niemieckie „prawo” okupacyjne w GG. Początek tego fragmentu monografii zasługuje moim zdaniem na akceptację. Przedstawiono w nim zakres ustawodawstwa niemieckiego w Generalnym Gubernatorstwie przy uwzględnieniu kryterium merytorycznego. Autor sięgnął tu do opracowania 
Alberta Weha ${ }^{9}$. Był to urzędnik wysokiego szczebla, który przez cały okres okupacji nadzorował pod względem technicznym i redakcyjnym niemiecką legislację w GG. Zajmował stanowisko kierownika Wydziału Ustawodawstwa, a potem Urzędu Ustawodawczego. Podział wewnętrznego zbioru przepisów opracowany przez A. Weha pozwala czytelnikowi zapoznać się z szerokim zakresem i szczegółowością ustawodawstwa okupacyjnego. Kolejne fragmenty tego punktu budzą jednak moje wątpliwości. Szulczyński uzasadnia dalszy tok narracji następująco:

— sądy polskie w GG obowiązywały wszystkie przepisy władzy okupacyjnej i musiały być one również uwzględniane przy orzekaniu - a było ich niemało. Niektóre zmieniały polskie prawo, narzucając przepisy i regulacje drastycznie niesprawiedliwe, szczególnie wobec Żydów, i stanowiły prawne narzędzia realizacji politycznych celów okupanta. Najważniejsze z nich należy tedy wskazać i omówić. (s. 90)

Rozumiem powody, dla których wyodrębnił on akty normatywne dyskryminujące ludność żydowską. Trzeba jednak podkreślić, że nie uwzględnił wszystkich tych aktów. W sumie na s. 90-97 przytoczył i krótko omówił kilkanaście aktów normatywnych, ale według mnie nie uzasadnił, dlaczego uznał je za najważniejsze spośród prawie 1700 aktów opublikowanych na łamach urzędowego publikatora Generalnego Gubernatorstwa. Poza tym kilka z kilkunastu cytowanych aktów wprowadza właściwość sądownictwa niemieckiego, a nie sądów polskich (nieniemieckich).

Na początku rozdziału trzeciego zawarta została statystyka wpływu spraw cywilnych i karnych do Sądu Okręgowego w Lublinie i do Sądu Okręgowego w Zamościu w latach 1939-1944, zamieszczona w nieopublikowanym opracowaniu Józefa Mazurkiewicza i Leopolda Polichy ${ }^{10}$. Za ogólną charakterystykę funkcjonowania sądownictwa polskiego uznać można rozważania oparte na analizie zawartości jednej teczki archiwalnej, w której zgromadzono okólniki i zarządzenia prezesa Sądu Okręgowego w Warszawie z okresu: grudzień 1939-grudzień 1941 roku (s. 100-103). Na kolejnych stronach autor odwołał się do wybranych przykładów orzecznictwa sądów polskich, dokonując słusznego podziału na sprawy cywilne (punkt 1) i karne (punkt 2). Struktura wewnętrzna tych punktów wiąże się z omawianiem wyników kwerend w poszczególnych archiwach. Kryterium to można uznać wyłącznie za zabieg porządkowy, gdyż nie wskazano innych elementów (na przykład wyznaczników odróżniających między sobą orzecznictwo poszczególnych sądów). Czytelnik odnajduje tu dane na temat zasobów kilku archiwów i przechowywanych w nich zespołów zawierających akta sądowe odnoszące się do problematyki monografii. Ponawiam moją uwagę, że informacje takie powinny być zamieszczone w punkcie 3 wstępu.

Rozdział trzeci zawiera skrótowe omówienie przebiegu i wyniku kilkudziesięciu spraw sądowych. Były to postępowania toczone przed Sądem Okręgowym

\footnotetext{
9 A. Weh, op. cit., passim.

10 J. Mazurkiewicz, L. Policha, op. cit., s. 47.
} 
w Warszawie, Sądem Okręgowym w Lublinie, Sądem Grodzkim w Lublinie, Sądem Grodzkim w Biłgoraju, Sądem Grodzkim w Puławach, Sądem Grodzkim w Sandomierzu. Uwzględniono więc orzecznictwo wybranych sądów mających swoje siedziby w trzech okręgach Generalnego Gubernatorstwa: warszawskiego, lubelskiego i radomskiego. Zabrakło orzecznictwa sądów polskich (nieniemieckich) z okręgu krakowskiego oraz orzecznictwa sądów nieniemieckich z dystryktu Galicja (ale w odniesieniu do dystryktu Galicja rozumiem odmienne podejście badawcze autora i nie kwestionuję jego poglądów naukowych w tym zakresie). Brakuje mi klarownego kryterium wyboru przedstawionych w monografii konkretnych spraw sądowych spośród bardzo dużej liczby innych postępowań, których akta zachowały się w spenetrowanych przezeń archiwach. W takiej sytuacji trudno pokusić się o kompleksowe, pogłębione konkluzje i uogólnienia. Na pewno jednak w rozdziale tym przedstawione zostały szczegółowo fakty nieznane dotąd historykom ustroju i prawa, które mogą zostać wykorzystane w dalszych badaniach naukowych. Dziwią mnie tylko decyzje autora o wyborze spraw, w których podsądnymi były osoby narodowości żydowskiej, ze względu na tytuł następnego rozdziału czwartego (Sady polskie w Generalnym Gubernatorstwie wobec Żydów). Wydaje mi się, że w takiej sytuacji postępowania sądowe, w których uczestniczyli Żydzi, powinny zostać omówione właśnie w rozdziale czwartym.

Treść ostatniego rozdziału, czwartego, jest adekwatna do wskazanego w poprzednim akapicie tytułu i odnosi się do statusu procesowego ludności żydowskiej przed sądami polskimi. Wywody autora $\mathrm{w}$ tym fragmencie monografii oparte pozostały przede wszystkim na najnowszej literaturze naukowej i aktach normatywnych obowiązujących w Generalnym Gubernatorstwie w okresie okupacji niemieckiej podczas drugiej wojny światowej. Przytoczone też zostały znane już ustalenia z rozdziału trzeciego, oparte na archiwaliach, co moim zdaniem uznać można za usterkę konstrukcyjną, gdyż w miarę możliwości należy unikać powtórzeń. Rozważania autora w rozdziale czwartym przedstawiają rolę sądownictwa polskiego oraz polskich adwokatów w procesie ograniczania praw i wolności ludności żydowskiej oraz grabieży jej majątków przez organy okupacyjne państwa niemieckiego. Szulczyński podjął tu dojrzałą dyskusję naukową z innymi historykami. Jego argumentacja opiera się zarówno na rzetelnym zastosowaniu metody historycznej, jak i na solidnym wykorzystaniu metody dogmatycznej (analiza aktów normatywnych). Polemikę tę kończy następującą oceną:

Reasumując na podstawie przytoczonych wyżej licznych przykładów zaczerpniętych z kwerend można uznać, że sądy polskie w Generalnym Gubernatorstwie tak w sprawach karnych, jak i cywilnych z udziałem Żydów zachowywały — pomijając nieliczne wyjątki - bezstronność i prawniczy, sędziowski obiektywizm. Inna rzecz, iż w wielu „sprawach żydowskich” mniej lub bardziej wyraźnie ujawnia się bezsilność polskich sądów na styku z wielkim obszarem bezprawia, na jakie skazana była cała żydowska społeczność. Ten problem, jak i oceny postaw moralnych adwokatów czy sądowników w GG powinny stać się tematem osobnej pracy. (s. 160) 
W zakończeniu autor dokonał podsumowania swoich ustaleń. Zgodził się $\mathrm{z}$ przeważającą $\mathrm{w}$ dotychczasowej literaturze naukowej pozytywną oceną sądownictwa polskiego funkcjonującego pod nadzorem okupanta niemieckiego w Generalnym Gubernatorstwie w latach 1939-1945. Podkreślił, że kontakty z organami niemieckiej administracji miały charakter merytoryczny i były wolne od ideologii. Stwierdził, że sądy polskie w GG nigdy nie stały się organami represji — niemiecki aparat terroru i represji działał poza nimi. Powołał się na ocenę sformułowaną przez struktury Polskiego Państwa Podziemnego o niewielkiej skali ingerencji Niemców w działalność sądownictwa polskiego. Jego stanowisko najlepiej ilustruje następujący cytat:

Ostatecznie podsumowując, należy stwierdzić, że pod pewnym względem można samo istnienie i funkcjonowanie sądownictwa polskiego w Generalnym Gubernatorstwie ocenić pozytywnie. Sądy polskie były wszak jedyną instytucją państwową II Rzeczypospolitej, która funkcjonowała na podstawie polskiego prawa niemal nieprzerwanie przez cały okres niemieckiej okupacji. Dzięki temu natychmiast po wejściu Niemców polskie sądy mogły przystąpić do działania. (s. 168)

Warunki podejmowania tej działalności w trakcie działań wojennych w latach 1944-1945 były niekiedy ekstremalne. Szulczyński przytacza tu mało znany fakt zatrzymania w 1945 roku polskich sędziów i prokuratorów w Kielcach i Radomiu przez organy sowieckie. Decydujące znaczenie miało jednak jednoznaczne rozstrzygnięcie prawomocności postępowań i orzeczeń sądów polskich działających w ramach okupacyjnego sądownictwa w Generalnym Gubernatorstwie (dekret z 6 czerwca 1945 roku o mocy obowiązującej orzeczeń sądowych, wydanych w okresie okupacji niemieckiej na terenie Rzeczypospolitej Polskiej) ${ }^{11}$. W pełni podzielam oceny $\mathrm{i}$ opinie autora monografii zawarte $\mathrm{w}$ zakończeniu.

Monografia Andrzeja Szulczyńskiego oparta została na umiejętnie wyselekcjonowanej, reprezentatywnej literaturze naukowej. Brakuje chyba tylko podanych $\mathrm{w}$ przypisie 2 trzech prac Huberta Mielnika. Autor nie sięgnął do tych opracowań, ale nie można czynić mu z tego powodu zarzutów, gdyż w chwili przygotowywania do druku monografii dostępny był tylko jeden artykuł Mielnika (wydany w Czechach w języku angielskim). Poza tym wymieniona wśród pozycji literatury naukowej publikacja Zygmunta Klukowskiego powinna być moim zdaniem zaliczona do źródeł drukowanych ${ }^{12}$.

Wykorzystane w recenzowanej monografii źródła drukowane stanowią solidny zbiór. Natomiast odczuwam niedosyt w odniesieniu do kwerendy archiwalnej. A. Szulczyński sięgnął do zbiorów tylko kilku archiwów i nie wyjaśnił, dlaczego wybrał właśnie te, a nie inne. W rezultacie całkowicie pominięta została spuścizna aktowa sądów z dwóch dystryktów. W wypadku dystryktu Galicja można

11 Dekret z dnia 6 czerwca 1945 roku o mocy obowiązującej orzeczeń sądowych, wydanych w okresie okupacji niemieckiej na terenie Rzeczypospolitej Polskiej, Dz.U. Nr 25, poz. 151.

12 Z. Klukowski, Zamojszczyzna 1918-1959, Warszawa 2007. 
ten stan rzeczy zaakceptować, gdyż wynika on z omówionych wcześniej założeń metodologicznych przyjętych przez autora. Nie widzę takiego usprawiedliwienia odnośnie do niewykorzystania akt sądów polskich (nieniemieckich) działających w czasie okupacji na terenie dystryktu krakowskiego (akta te są dostępne na przykład w Archiwum Narodowym w Krakowie). Trzeba też dodać, że przywołane w recenzowanej książce akta sądów z dystryktu lubelskiego pochodzą z Archiwum Państwowego Instytutu Pamięci Narodowej w Warszawie - Komisji Ścigania Zbrodni przeciwko Narodowi Polskiemu. Wydaje się więc, że Szulczyński nie przeprowadził kwerendy $w$ archiwach mających swe siedziby na terenie Lubelszczyzny.

Recenzowana monografia nie jest według mnie kompleksową syntezą, całościowo ujmującą skomplikowaną problematykę organizacji i funkcjonowania sądownictwa polskiego w Generalnym Gubernatorstwie podczas drugiej wojny światowej. Sformułowane przeze mnie opinie i oceny mają charakter polemiczny i często krytyczny. Doceniam jednak także zalety tej publikacji. Podtrzymuję więc moje stanowisko zawarte w artykule recenzyjnym opublikowanym wcześniej w „Studiach z Dziejów Państwa i Prawa Polskiego”:

zachęcam do lektury książki pt. Sąownictwo polskie w Generalnym Gubernatorstwie 19391945. Na pewno stanowi ona jeden z ważnych kroków zmierzających do „otwarcia drzwi zamkniętych dotąd w polskiej historiografii”. Wiele przytoczonych przez Andrzeja Szulczyńskiego faktów to całkowita nowość, która w istotnym stopniu rozszerza stan naszej wiedzy. Nie można przejść obok tej publikacji obojętnie. Ustalenia dokonane przez Autora i sformułowane w monografii wnioski będą stanowiły asumpt, do koniecznych według mnie, dalszych badań nad sądownictwem na ziemiach polskich pod okupacją niemiecką w czasie II wojny światowej ${ }^{13}$.

\section{Bibliografia}

\section{Źródła}

Rozporządzenie w sprawie odbudowy wymiaru sprawiedliwości w okręgu Galizien (Galicja) z dnia 1 sierpnia 1941 r., Dziennik Rozporządzeń dla Generalnego Gubernatorstwa 1941, nr 68.

Dekret z dnia 6 czerwca 1945 roku o mocy obowiązującej orzeczeń sądowych, wydanych w okresie okupacji niemieckiej na terenie Rzeczypospolitej Polskiej, Dz.U. Nr 25, poz. 151.

Weh A., Prawo Generalnego Gubernatorstwa w układzie rzeczowym z objaśnieniami i szczegótowym skorowidzem, (wydanie trzecie podpisane przez A. Weha 31 grudnia 1940 r.), Kraków 1941.

A 100, Dekret Führera i Kanclerza Rzeszy Niemieckiej o administracji okupowanych polskich obszarów z dnia 12 października 1939 r.

C 100, Rozporządzenie o odbudowie wymiaru sprawiedliwości w Generalnym Gubernatorstwie z dnia 26 października $1939 \mathrm{r}$.

Klukowski Z., Zamojszczyzna 1918-1959, Warszawa 2007.

13 A. Wrzyszcz, Sądy na ziemiach polskich w czasie okupacji niemieckiej (1939-1945). Najnowsze opracowania tematu, „Studia z Dziejów Państwa i Prawa Polskiego” 23, 2020, s. 53. 


\section{Literatura naukowa}

Engelking B., Grabowski J., Przestępczośc” Żydów w Warszawie 1939-1942, Warszawa 2010.

Grabowski J., Zarzad powierniczy i nieruchomości żydowskie w Generalnym Gubernatorstwie, [w:] Klucze i kasa. O mieniu żydowskim w Polsce pod okupacja niemiecka $i$ we wczesnych latach powojennych 1939-1950, red. J. Grabowski, D. Libionka, Warszawa 2014.

Grabowski J., Żydzi przed obliczem niemieckich i polskich sądów w dystrykcie warszawskim Generalnego Gubernatorstwa, 1939-1942, [w:] Prowincja noc. Życie i zagłada w dystrykcie warszawskim, red. B. Engelking, J. Leociak, D. Libionka, Warszawa 2007.

Mazurkiewicz J., Policha L., Dzieje sądownictwa lubelskiego w latach 1915-1944, razem z notatką J. Mazurkiewicza i L. Polichy o stratach w lubelskim sądownictwie stworzoną na podstawie protokołów Miejskiej Komisji Badania Zbrodni Niemieckich w Lublinie, praca nieopublikowana, mpis przechowywany w Katedrze Historii Państwa i Prawa UMCS w Lublinie.

Mielnik H., The legal status of the Jews in proceedings before the Polish (non-German courts in the Lublin district of the General Governement during World War II, „Acta historico-iuridica Pilsnensia" 2018.

Mielnik H., Prawo sprawdzenia prawomocnych orzeczeń sąów polskich (nieniemieckich) w Generalnym Gubernatorstwie w okresie II wojny światowej. Orzecznictwo Wyższego Sądu Niemieckiego w Radomiu, „Czasopismo Prawno-Historyczne” 72, 2020, z. 1.

Mielnik H., Sadownictwo polskie (nieniemieckie) w dystrykcie lubelskim Generalnego Gubernatorstwa w latach 1939-1945, Lublin 2020.

Sworzeń M., Sądownictwo polskie w Generalnym Gubernatorstwie, „Prawo i Życie” 1987, nr 40.

Sworzeń M., Sędziowie w podbitym kraju. Oficjalne sądownictwo polskie w Generalnym Gubernatorstwie 1939-1945, „Zeszyty Historyczne” 1999, z. 128.

Szarycz J., Sędziowie i sądy w Polsce w latach 1918-1988, Warszawa 1988.

Wiatr E., Na marginesie funkcjonowania sąów polskich w Generalnym Gubernatorstwie. Przypadek Majera Wolberga, „Zagłada Żydów. Studia i materiały. Pismo Centrum Badań nad Zagładą Żydów IFiS PAN" 2015, nr 11.

Wrzyszcz A., O organizacji okupacyjnego sadownictwa polskiego w Generalnym Gubernatorstwie w latach 1939-1945, „Zeszyty Majdanka” 14, 1992.

Wrzyszcz A., Sady na ziemiach polskich w czasie okupacji niemieckiej (1939-1945). Najnowsze opracowania tematu, „Studia z Dziejów Państwa i Prawa Polskiego” 23, 2020. 